\title{
Dual Enrollment and College Success: Lessons from a Muslim School
}

\author{
Hassan Elannani (Corresponding author) \\ Knowledge and Human Development Authority \\ P.O. Box 500008, Dubai, United Arab Emirates \\ Tel: 971-4-364-0043Ｅ-mail: hassan.elannani@khda.gov.ae
}

Received: November 9, 2014 Accepted: January 5, 2015 Published: January 9, 2015

doi:10.5296/ire.v3i1.6885 URL: http://dx.doi.org/10.5296/ire.v3i1.6885

\begin{abstract}
Dual enrollment programs are expanding and more students from private schools have been benefitting from them academically and financially but only few Muslim schools have participated in these programs. Twelve students from a Muslim school were enrolled in a dual enrollment program at a local community college while completing their high school graduation requirements. The students' academic achievement during the dual enrollment period was examined and a follow-up of their college outcomes was conducted. These students graduated from high school one year earlier with distinction and earned two semesters of college credits. Ten students out of twelve graduated from universities three to four years after completing the dual enrollment program. These students benefitted from the community college experience during the dual enrollment program and acquired the necessary skills that helped them graduate from universities in the USA, Canada, and United Arab Emirates.
\end{abstract}

Keywords: Muslim schools, dual enrollment, dual credit, concurrent enrollment

\section{Background}

Dual enrollment, concurrent enrollment, and dual credit are all descriptors of an accelerated learning opportunity in which students enroll in college courses and receive college credit, often for free, while still in high school. Many states (82 percent) have provided dual enrollment programs to their high school students (U.S. Department of Education, 2005). A growing body of evidence indicated the benefits of dual enrollment programs on students. For example, they can increase high school graduation rates, enhance college enrollment and persistence, and decrease the costs of money and time to complete a college degree (Cassidy, 
Keating, \& Young, 2011). There is also growing fiscal benefit to students, families, and the community (Rochford, O’Neill, \& Gelb, 2009). In the short-term, there is some evidence of improved grades and progress toward high school graduation for participants in dual enrollment. In the long-term, research shows evidence of the apparent effects of dual enrollment on college success (Rodriguez, Hughes, \& Belfield, 2012).

More focused research has found a positive and strong association between dual enrollment participation and postsecondary outcomes for males and low-income students (Karp, Calcagno, Hughes, Jeong, \& Bailey, 2008). Dual enrollment students intend to continue their post-secondary education and have successful experiences in subsequent courses taken at the university (Woolstenhulme, Woolstenhulme, \& Lafferty, 2009; Windham \& Perkins, 2001). In general, studies have found that earning college credits prior to high school graduation increases the likelihood of earning a college degree and reduces time to complete college degrees (Adelman, 2006; Swanson, 2008).

In addition, career-technical students who participated in dual enrollment have shown higher college enrollment, grade point averages, and credit accumulation than similar careertechnical students who did not take dual enrollment courses (Karp et al., 2007). Thus, the combination of rigorous career-technicall education and dual enrollment has great potential to meet students' college and career readiness needs. Rochford, O’Neill, and Gelb (2009) found that nearly all high school-based dual enrollment students made plans to go to college, and 80 percent of high school- based dual enrollment students scored "B" or above. Research on the effect of dual enrollment on academic outcomes found that students enrolled in college algebra courses were more likely to go to college after high school. Dual enrollment also had a positive impact as a general indicator for degree attainment of an associate or a bachelor's degree (Speroni, 2001).

A comprehensive search of Muslim schools' websites yielded only three schools with published descriptions of their dual enrollment programs. Al-Noor Academy in Boston, Eman Schools in Indiana, and Al-Aqsa Islamic Academy in Philadelphia. Al-Noor Academy had a dual enrollment agreement with Quincy College and Bridgewater College that was open to students in grades 11 and 12. By the end of the 12th grade, students participating in this program had the opportunity to earn academic credits, which could save them up to two years of college. However, parents had to pay tuition directly to the college. Successful students were able to graduate with a high school diploma from Al-Noor Academy and graduate with an associate degree if they completed additional classes beyond Al-Noor Academy' requirements.

To be eligible for the dual enrollment program, students must attend 10th grade at Al-Noor Academy during which they should have a GPA of 3.3 or higher and show excellent conduct. In addition, students should demonstrate outstanding performance on achievement tests given by the school and the college. The school had the authority to withdraw students from the program if their academic performance and conduct were judged inappropriate. Dual enrollment students should also maintain a 3.0 GPA in both college and school classes every semester to prevent withdrawal from the program. The success of Al-Noor Academy's 
program was corroborated by the 2011 report of Massachusetts' Department of Higher Education, which showed that students in the state's dual enrollment program were very successful with course completion rates above 80 percent and an overall GPA of approximately 3.0.

The other two schools offering dual enrollment programs were Eman Schools in Indiana and Al-Aqsa Islamic Academy in Philadelphia. The Eman Schools made an agreement with Vincennes University and Ivy Tech Community College of Indiana to teach dual credit courses on school campus. Eman Schools selected only classes that were part of the Indiana Core Transfer Library in order that students' course credits could be accepted anywhere in Indiana. Graduates from Eman Schools who were enrolled in the dual credit program could complete 25 to 40 college credits by the time they finish high school. In the same manner, Al-Aqsa Islamic Academy in Philadelphia had a partnership with the Community College of Philadelphia to provide students in grades 11 and 12 with the opportunity to enroll in college courses while pursuing their high school education.

\section{Research Methods}

The Muslim school in this study was a private comprehensive academy governed and supported by the Muslim community center. In 2005, there were 250 students from kindergarten to grade 12. Fifteen teachers and administrators prepared students academically according to the state's curriculum standards in the core subjects of English, math, science, social studies, and physical education. Students also received education in Arabic language and in Islamic religion. The author was the principal of the school and was responsible for managing the dual enrollment program in collaboration with the local community college, which offered over 100 degree, diploma, and certificate programs to approximately 70,000 students in six campuses that were conveniently located across the county.

In 2005, only one student from the Muslim school joined the community college's dual enrollment program. More students joined in the following year after the success of the first student in overcoming successfully the demands of high school and college courses. The students were also encouraged to participate in this program because the community college offered them free tuition, college credits, career exploration, and college transfer pathways.

To be qualified for dual enrollment, the Muslim school required candidates to pass grade 10 with a "B" average, show good character, attend Muslim school's classes regularly, and maintain a community college GPA of at least 3.0. Twelve students participated in the dual enrollment program from 2005 to 2008. They were eleven girls and one boy. The gender gap was due to the very limited number of boys in high school at that time. Students had access to dual enrollment in the summer of 2005 right after the completion of their sophomore year. All enrollees graduated from high school in grade 11 after fulfilling the state graduation requirements.

To undertake this research, a quasi-experimental and longitudinal design was used to follow up the students' college graduation outcomes after the completion of the dual enrollment program. The design was internally valid because dual enrollment preceded college 
graduation in time; both were related to each other; and all other alternative explanations were minimized. Evidence of students' achievement in grade 11 was taken from their results on report cards and high school diplomas issued by the Muslim school. Evidence of students' college graduation was taken from communications with students through social media, alumni news from the websites of the Muslim school, and graduation information from colleges/universities attended previously by the students.

\subsection{Research Questions}

Evidence from research has indicated a strong impact of dual enrollment on college success. This study sought to corroborate these findings in the context of a Muslim school and to examine the effect of dual enrollment on academic achievement in high school. The underlying prediction of this study was that dual enrollment at the Muslim school had contributed positively to students' high school achievement and the completion of their college degrees. To prove this hypothesis, the following questions were used to guide the research findings and discussion:

a. What was the high school achievement of students in the dual enrollment program?

b. What was the college achievement of students in the dual enrollment program?

\section{Findings and Discussion}

\subsection{High School Achievement}

The cohorts of students from the Muslim school who participated in the dual enrollment program demonstrated well-developed personal and academic characteristics that helped them achieve their individual goals at school and fulfill their academic aspirations in the community college. Throughout the program, the students displayed commitment to education, good achievement in academic subjects, high college aspirations, collaboration at school and at the community college, and sound character. Parental support was very crucial in maintaining these positive attitudes and making the experience successful overall.

During their high school journey, the enrollees were required to attend school daily or only on specific days, depending on the school and college course schedules. They were able to navigate school and college requirements with diligence and persistence. Their good class attendance rates at school and timely completion of assignments demonstrated appropriate management skills of school and college tasks. In addition, they were able to participate in major school events and in leading the activities of the student council. Commuting between school and college was accessible through car-pooling provided by parents and the ability of some students to drive their own cars.

Preparation for college was not limited to high school studies and courses taken at the community college. Students also took college entrance examinations such as PSAT and SAT, and few of them began the process of seeking admission to universities and four-year institutions early in grade 11. Most students in the group benefitted from dual enrollment in their search for suitable programs and financial aid opportunities. For example, a private college awarded a scholarship to one student to study pharmacy, but the student preferred to 
join a Canadian university instead.

All twelve students who participated in the dual enrollment program graduated from the Muslim school by grade 11 in years 2007 and 2008. They completed all the state graduation requirements in addition to earning credits from the community college, which were treated by the school at the honors level. For example, a grade of $B$ earned at the college was reflected as an A on the high school transcript, and a grade of A was translated into an A+. In consequence, students' GPA improved significantly and the college-level courses on their transcripts increased in number.

Evidence from enrollees' academic experience showed that dual enrollment at the community college improved their achievement in high school to a large degree. They found the core school subjects, especially math and English, easily manageable, and showed good progress in other subjects such as Arabic and Islamic Studies. As a result, the twelve students in the dual enrollment program graduated by grade 11 with distinction. College classes did not prevent them from participating in major school events and in student council activities. They demonstrated a high level of flexibility and adaptability to demands on their time and effort, and showed motivation and drive to fulfill their dreams. By the end of grade 11, they saved one full year of high school and earned two semesters of free college education. Their high school transcripts carried high GPA grades and credits from several college courses, which entitled them to a high school diploma recognized by the state and institutions of higher education.

\subsection{College Achievement}

The community college treated the students from the Muslim school as regular college students. In addition, it provided them with free tuition and fees, but students had to buy their own textbooks. All twelve students who entered the dual enrollment program had to take placement tests in English and math. If they passed, they were able to enroll in the two required introductory courses: Expository Writing and Applied Math. Students who did not pass tests in the first time could still choose from a variety of college-level courses that did not require prerequisites. These courses included Art Appreciation, Principles of Biology, Introduction to Business, Concepts in Chemistry, Introduction to Communication, Introductory Geology, World Regional Geography, World Civilizations, International Business, Conceptual Physics, American Government, and General Psychology.

Based on the Muslim school's policy, students had to demonstrate good academic standing at the community college in order to maintain continuous participation in the dual enrollment program. Students had to submit end of semester college transcripts to the principal to check if all courses received at least the required " $B$ " grade. In addition, students discussed their choices of courses with the principal to prevent time conflicts with school classes. In case of conflict, the principal met with students and parents to discuss alternativesi and secure parents' logistical support to attend school and college classes on time.

In comparing the three Muslim schools mentioned earlier (see Background) with the one in this study, it becomes clear that they administered dual enrollment programs over two years 
while the Muslim school in this study had an accelerated dual enrollment program of only one year in grade 11, which allowed students to shorten the time of high school education and provide them with the opportunity to earn between 18 and 33 college credits in a period of one summer session and two semesters (Fall and Spring).

After graduation from the Muslim school, a small number of students chose to continue their studies at the community college to earn associate degrees before joining universities or four-year colleges. Table 1 showed that, from the group of twelve students, eight graduated from a regional university with bachelor's degrees in chemistry, psychology, biology, health sciences, English \& middle grades education, civil engineering, and business \& marketing. One student graduated from a Canadian university with a bachelor's in mathematics \& psychology and another student graduated from a business college in the United Arab Emirates. Two students are enrolled currently in college after delaying their higher education few years because of marriage.

Table 1. The destinations and majors of dual-enrollment students

\begin{tabular}{llc}
\hline \multicolumn{1}{c}{ Destinations } & \multicolumn{1}{c}{ Majors } & Total students \\
\hline $\begin{array}{l}\text { US colleges and } \\
\text { universities }\end{array}$ & $\begin{array}{l}\text { Chemistry, psychology, biology, health sciences, English \& middle grades } \\
\text { education, civil engineering, business \& marketing }\end{array}$ \\
Canada & Mathematics \& psychology & 1 \\
United Arab & Business & 1 \\
Emirates & & \\
\hline
\end{tabular}

\section{Conclusion}

Dual enrollment programs for Muslim schools help build strong partnerships with the parents, students and with institutions of higher education. The provision of such intensive college programs helps high school students, especially from minority groups, to achieve their college education aspirations. The dual enrollment program was a great benefit to the Muslim school, parents, and students. It helped the school build a strong partnership with the community college and develop its capacity to guide students into higher education. The program also helped this small and less-resourced school to save on expenses needed to offer AP and elective courses to students in grades 11 and 12. Parents benefitted financially by saving one year of school tuition and one year of college fees. More importantly, the program exposed students to college life early and equipped them with the necessary skills to succeed in higher education. As a result, ten students out of twelve graduated from universities and colleges three to four years after completing the dual enrollment program.

\section{References}

Al-Noor Academy. (2013). Dual enrollment program. Retrieved from http://www.anahs.org/docs/dualenrollmentprogram.pdf

Alfeld, C., \& Bhattacharya, S. (2013). Mature programs of study: Examining policy implementation at the local level. Retrieved from http://www.nrccte.org/sites/default/ 
files/publication-files/nrccte_mature_pos_final.pdf

Allen, D. (2010). Dual enrollment: A comprehensive literature review \& bibliography. Retrieved from http://www.cuny.edu/academics/k-to-12/databook/library/DE_LitReview _August2010.pdf

An, B. P. (2013). The impact of dual enrollment on college degree attainment: Do less-SES students benefit? Educational Evaluation and Policy Analysis, 35(1), 57-75. http://dx.doi.org/10.3102/0162373712461933

Cassidy, L., Keating, K. \& Young, V. (2011). Dual enrollment: Lessons learned on school-level implementation. Retrieved from http://www2.ed.gov/programs/slcp/finaldual.pdf

Catron, R. K. (2001). Dual Enrollment in Virginia. New Directions for Community Colleges, 2001(113), 51-58. http://dx.doi.org/10.1002/cc.8

Department of Higher Education. (2011). Commonwealth dual enrollment program: 2008-2010 outcomes. Retrieved from http:/www.mass.edu/library/documents/ CDEP\%/202008-2010\%20Outcomes.pdf

Eman Schools. (2013). Dual credit-Vincennes \& Ivy Tech. Retrieved from http://emanschool.net/

Farrell, P. L., \& Seifert, K. A. (2007). Lessons learned from a dual-enrollment partnership. New Directions for Community Colleges, 2007(139), 69-77. http://dx.doi.org/10.1002/cc.294

Fleischman, S. \& Heppen, J. (2009). Improving low-performing high school: Searching for evidence of promise. The Future of Children, 19(1), 105-133. http://dx.doi.org/10.1353/foc.0.0021

Flores, A. L. A. (2012). Dual enrollment Programs: A comparative study of high school students' college academic achievement at different settings. (Unpublished doctoral dissertation). Corpus Christi, Texas: Texas A\&M University-Corpus Christi.

Hoffman, N., Vargas, J., \& Santos, J. (2008). On ramp to college: A state policymaker's guide to dual enrollment. Retrieved from http://www.jff.org/publications/education/ramp-college-state-policymaker\%E2\%80\%99s-gui de-d/210

Hughes, K. L. (2010). Dual Enrollment: Postsecondary/Secondary Partnerships to Prepare Students. Journal of College Science Teaching, 39(6), 12-13. Retrieved from http://ccrc.tc.columbia.edu/publications/dual-enrollment-postsecondary-secondary.html

Judd, D. R., Woolstenhulme, D. R., Woolstenhulme, K. J., \& Lafferty, V. J. (2009). Comparing the Impact of Televised and Face-to-Face Dual Enrollment Programs on Student Satisfaction and Subsequent Enrollment Choices. Online Journal of Distance Learning Administration, 12(2). Retrieved from http://www.westga.edu/ distance/ ojdla/summer122/judd122.pdf

Karp, M. M., Calcagno, J. C., Hughes, K. L., Jeong, D. W., \& Bailey, T. (2008). Dual 


\section{Macrothink Institute ${ }^{\mathrm{TM}}$}

Enrollment Students in Florida and New York City: Postsecondary Outcomes. Retrieved from http://academiccommons.columbia.edu/catalog/ac\%3A157420

Kim, J., Kirby, C., \& Bragg, D. D. (2006). Dual credit: Then and now. In Brief. Retrieved from http://occrl.illinois.edu/files/InBrief/Brief-spring-06.pdf

Kronholz, J. (2011). High schoolers in college. Education Next, 11(3), 27-31. Retrieved from http://educationnext.org/high-schoolers-in-college/

Rochford, J. A., O’Neill, A., \& Gelb, A. (2009). Advancing college opportunity: An impact evaluation of the growth of dual credit in Stark and Wayne counties, Ohio. Retrieved from http://www.starkcountyesc.org/Downloads/1\%20SEP\%20Report\%2008-09.pdf

Rodriguez, O., Hughes, K. L., \& Belfield, C. (2012). Bridging college and careers: Using dual enrollment to enhance career and technical education pathways. Retrieved from http://www.postsecondaryresearch.org/i/a/document/NCPRBrief_RodriguezHughesBelfield_ DualEnrollment.pdf

Rosenbaum, J. E., \& Becker, K. I. (2011). The early college challenge: Navigating disadvantaged students' transition to college. American Educator, 35(3), 14-20. Retrieved from http://www.aft.org/pdfs/americaneducator/fall2011/EarlyCollege.pdf

Speroni, C. (2011). High school dual enrollment programs: Are we fast-tracking students too fast? Retrieved from http://www.postsecondaryresearch.org/i/a/document/NCPRBrief_ Speroni_DE.pdf

Texas Education Agency (2010). Research study of Texas dual credit programs and courses. Retrieved from http://www.tea.state.tx.us/index2.aspx?id=2147495222

U.S. Department of Education (2005). Update to state dual enrollment policies: Addressing access and quality. Retrieved from http://www2.ed.gov/about/offices/list/ovae/pi/cclo/ cbtrans/statedualenrollment.pdf

Vargas, J. \& Quiara, J. (2010). Policies paved the way: early college innovation in North Carolina. Retrieved from http://www.jff.org/publications/education/policies-pavedway-early-college-innovat/1012

Windham, P., \& Perkins, G. (2001). Dual Enrollment as an Acceleration Mechanism: Are Students Prepared for Subsequent Courses? Paper prepared for the 41st Annual Association forInstitutional Research Forum, Long Beach, CA. Retrieved from http://www.fldoe.org /fcs/ chancellor/newsletters/clips/DE_as_an_Acceleration_Mechanism.htm

\section{Copyright Disclaimer}

Copyright reserved by the authors.

This article is an open-access article distributed under the terms and conditions of the Creative Commons Attribution license (http://creativecommons.org/licenses/by/3.0/). 